\title{
TRIBUTE TO HEINZ HOLTER
}

by

\author{
CHRISTIAN DE DUVE
}

It is a pleasure to join in this tribute to HEINZ HOLTER, chemist and biologist, scientist and humanist, and, especially, warm human being and dear friend.

When our paths first crossed, HEINZ already had to his credit the awesome accomplishments issued from his collaboration with LINDERSTRøM-LANG and resulting in the development of the most refined techniques ever invented for the purpose of correlating structure and function. I myself had just begun to use the contrastingly brutal and coarse methods of mass homogenization and fractionation, which, ironically, were destined to reach a resolution that even the most perfected form of miniaturization never achieved. It is, I believe, significant in this respect that HEINZ in no way was blinded by his dedication to the ultra-micro. He was among the first to recognize the immense potentialities of cell fractionation and made characteristically original contributions to this new approach. With MARTIN OTTESEN and RUDOLF WEBER, he inaugurated density equilibration in a sucrose gradient as a means of separating cytoplasmic particles (1). Unlike most subsequent users of this technique, he was concerned about the physical effects of the high sucrose concentrations needed to reach appropriate density levels. In order to minimize such effects, the workers incorporated "Diodon", an iodinated solute of high density, into their gradients. Later, with KNUd MaX Møller (2), Heinz defined with remarkable insight the properties of the ideal solute: "sufficiently high molecular weight to insure low osmotic activity even in highly concentrated solutions, sphaerical molecules to insure low viscosity, high solubility in water and weak salt solutions, chemical inertness and sta- bility to autoclaving, lack of toxicity, absence of nitrogen (so as not to prevent KJELDAHL analysis) - and fianally, as high specific gravity as possible." As nature failed to oblige, HeINZ simply had the portrait fulfilled by chemists in the Swedish firm Pharmacia. The result was "Ficoll", which, in addition to meeting most of the ordered specifications, turned out to have an advantage not included in the order. With its molecular weight of only 50,000 , it did not have the high sedimentation coefficient that complicated the use of many other macromolecules. Incidentally, HEINZ'S original "Diodon" idea has also led to a fruitful development, that of Metrizamide, an iodinated carbohydrate derivative, by NYEGAARD and Co. in Oslo.

Not so much techniques, however, as a common interest in intracellular digestion brought HEINZ and me together in the late 1950s. Here again, our departures had been very different. Whereas I had been led to intracellular digestion more or less in the manner of a blind man obeying, not without some reluctance, the pull of his dog - taking the guise, as it happened, of a biochemically characterized bag of hydrolytic enzymes - HEINZ took the more logical and inspired course of the biologist following his curiosity. With John Marshall, Cicily CHAPMAN-ANDRESEN, and others, he had embarked in a study of pinocytosis in amoebae and had, in a few years' time, arrived at the perceptive conclusion that "the definition of the phenomenon may have to be modified so that less emphasis is placed on the uptake of fluid and more on the uptake of dissolved substances" (3). He thus contributed to resurrect the opinion, already propounded by WARREN LEWIS, the discoverer of pinocytosis (4), that this process 
might, similarly to phagocytosis, lead to the uptake of complex substances requiring digestion to be utilizable.

In this field, also, HEINz HoLTER acted as an innovator, ahead of his time. His discovered adsorptive pinocytosis and guessed that it might serve as a means of selective intracellular uptake of extracellular materials. He tried to measure the rate of uptake of fluid and solutes quantitatively and pointed to the amount of surface membrane that comes to be interiorized in the process, long before these became fashionable topics of investigation. Ever diffident, HEINZ felt that he almost had to apologize for evincing an interest in something as offbeat as the drinking habits of amoebae, hardly worthy of mention in an "august mammalian assembly" (the 1963 Ciba Foundation Symposium on Lysosomes, ref. 5). The tremendous recent upsurge of interest in receptor-mediated endocytosis, membrane recycling, and related subjects should be a source of considerable satisfaction to our distinguished octogenarian friend.

Most remarkable, perhaps, about the richly productive scientific career of HEINZ HOLTER is the shroud of unobstrusive modesty in which it is cloaked. No scientist that I know has suc- ceeded better than HeINZ in making so many important contributions and claiming so little credit for them. In this, no doubt, he showed true wisdom, preferring the deep inner satisfaction of research and discovery to the vanities of public recognition, and the value of authentic personal friendships to the unseemly competitiveness and distrust that too frequently mar the relationships between scientists nowadays. In wishing HEINZ many more years of rewarding contemplation and enjoyment of life, I think also with fond remembrance of his gentle, beloved KAREN, whose memory lives on in the minds of all those who had the privilege of being guests in the HOLTER home.

\section{REFERENCES}

1. Holter, H., M. Ottesen \& R. Weber: Experientia (Basel), 9, 346-352 (1953)

2. Holter, H. \& K. Max Møller: Exp. Cell Res. 15, 631-632 (1958)

3. Holter, H.: Int. Rev. Cytol. 8, 481-504 (1959)

4. LEWIS, W.H.: Bull. Johns Hopkins Hosp. 49, 17-27 (1931)

5. Holter. H.: In: Lysosomes (de Reuck, A.V.S. and Cameron, M.P., eds.), J. \& A. Churchill, Ltd., London, p. 198 (1963) 